\title{
Mercury levels of marine fish commonly consumed in Peninsular Malaysia
}

\author{
Nurul Izzah Ahmad • Mohd Fairulnizal Mohd Noh • Wan Rozita Wan Mahiyuddin • \\ Hamdan Jaafar • Ismail Ishak • Wan Nurul Farah Wan Azmi • Yuvaneswary Veloo • \\ Mohd Hairulhisam Hairi
}

Received: 18 June 2014 / Accepted: 28 August 2014 / Published online: 26 September 2014

(C) The Author(s) 2014. This article is published with open access at Springerlink.com

\begin{abstract}
This study was conducted to determine the concentration of total mercury in the edible portion of 46 species of marine fish $(n=297)$ collected from selected major fish landing ports and wholesale markets throughout Peninsular Malaysia. Samples were collected in June to December 2009. Prior to analysis, the fish samples were processed which consisted of drying at $65{ }^{\circ} \mathrm{C}$ until a constant weight was attained; then, it was grounded and digested by a microwave digestion system. The analytical determination was carried out by using a mercury analysis system. Total mercury concentration among fish species was examined. The results showed that mercury concentrations were found significantly higher $(p<0.001)$ in demersal fish (the range was from 0.173 to $2.537 \mathrm{mg} / \mathrm{kg}$ in dried weight) compared to pelagic fish (which ranged from 0.055 to $2.137 \mathrm{mg} / \mathrm{kg}$ in dried weight). The mercury concentrations were also higher in carnivorous fish especially in the species with more predatory feeding habits. Besides, the family group of Latidae $(0.537 \pm 0.267 \mathrm{mg} / \mathrm{kg}$ in dried weight), Dasyatidae $(0.492 \pm 0.740 \mathrm{mg} / \mathrm{kg}$ in dried weight), and Lutjanidae ( $0.465 \pm 0.566 \mathrm{mg} / \mathrm{kg}$ in dried weight) showed significantly $(p<0.001)$ higher mercury levels compared to other groups. Fish collected from Port Klang $(0.563 \pm$ $0.509 \mathrm{mg} / \mathrm{kg}$ in dry weight), Kuala Besar $(0.521 \pm 0.415 \mathrm{mg} / \mathrm{kg}$
\end{abstract}

Responsible editor: Philippe Garrigues

N. I. Ahmad $(\bowtie) \cdot$ M. F. M. Noh • W. R. W. Mahiyuddin •

W. N. F. W. Azmi $\cdot$ Y. Veloo $\cdot$ M. H. Hairi

Institute for Medical Research, Jalan Pahang, 50588 Kuala Lumpur,

Malaysia

e-mail: nurul@imr.gov.my

H. Jaafar

Fisheries Biosecurity Centre, Department of Fisheries Malaysia, Lot 82, Jalan Carruthers, Off Jalan Sultan Salahuddin, 50480 Kuala Lumpur, Malaysia

I. Ishak

Fisheries Research Institute, 11960 Batu Maung, Penang, Malaysia in dry weight), and Pandan $(0.380 \pm 0.481 \mathrm{mg} / \mathrm{kg}$ in dry weight) were significantly higher $(p=0.014)$ in mercury concentrations when compared to fish from other sampling locations. Total mercury levels were significantly higher $(p<0.002)$ in bigger fish (body length $>20 \mathrm{~cm})$ and were positively related with fish size (length and weight) in all fish samples. Despite the results, the level of mercury in marine fish did not exceed the permitted levels of Malaysian and JECFA guideline values at $0.5 \mathrm{mg} / \mathrm{kg}$ methylmercury in fish.

Keywords Total mercury $\cdot$ Marine fish $\cdot$ Demersal fish . Pelagic fish · Fish landing ports $\cdot$ Wet market $\cdot$ Peninsular Malaysia

\section{Introduction}

Fish is an important source of protein in Malaysia. Daily consumption of fish is on average one and a half medium fish per day (Norimah et al. 2008). The Malaysian per capita consumption of fish was $56.39 \mathrm{~kg} /$ person/year in the year 2003 and accounted for $12.4 \%$ of total food intake per capita (Tey et al. 2008). The results of the Household Expenditure Survey for Malaysia in 2004/2005 showed that budget shares on fish $(22.1 \%)$ was the second largest after cereals $(23.9 \%)$, and the trend showed an increase when compared to the previous 1999/2000 survey (21.8 \%). A study on food consumption behavior among Malays showed that the consumers were not affected by the changes in fish price, where an increase in the expenditure on fish may be caused by increment of income together with an increase in the health consciousness (Tey et al. 2008).

Many researchers have discussed the benefits of seafood and bioactive components from aquatic sources in relation to various health outcomes (Larsen et al. 2011; McManus et al. 2011; Torpy 2006). Marine fish has a favorable fatty acid 
composition, namely, the long-chain $\mathrm{n}-3$ polyunsaturated fatty acids (n-3 PUFA), the eicosapentaenoic acid (EPA; C20:5n3 ), and the docosahexaenoic acid (DHA; C22:6n-3) that has been linked to a lower incidence of cardiovascular disease (CVD) (Larsen et al. 2011; McManus et al. 2011; Torpy 2006). High-quality fish proteins contain all the essential amino acids and are highly digestible (Larsen et al. 2011). The bioactive properties from fish proteins and peptides have been reported to be an antihypertensive, antioxidative, anticoagulant, and antimicrobial components in functional foods or nutraceuticals and pharmaceuticals. Marine foods are also excellent source of essential nutrients such as minerals (iodine and selenium) and vitamins (vitamins $\mathrm{A}, \mathrm{D}$, and $\mathrm{B}_{12}$ ). Other marine bioactive components linked to health promoting effects include taurine, phytosterols, antioxidants, and phospholipids (Larsen et al. 2011; McManus et al. 2011; Torpy 2006).

Conversely, fish consumption is the major route of mercury exposure to human and it is often found in the form of methylmercury (Burger 2009; Morgano et al. 2011; CastroGonžalez and Mendez-Armenta 2008; Myers and Davidson 2000). Fish may concentrate methylmercury either directly through the water or through components of the food chain (Castro-Gonžalez and Mendez-Armenta 2008). Mercury attached to aquatic sediments is subject to microbial conversion to methylmercury, at which point it enters the aquatic food chain and reaches its highest concentration in predatory fish (Clarkson et al. 2003). The cyclic order of mercury contamination chain starts from its emission in industries. This is followed by contamination in atmosphere, soil, water, phytoplankton, zooplankton, fish, and to human (Castro-Gonžalez and Mendez-Armenta 2008). There are two important sources of mercury which are anthropogenic and natural sources. The most important source is from the anthropogenic sources particularly from urban discharges, agricultural materials, mining and combustion, and industrial discharges (CastroGonžalez and Mendez-Armenta 2008; Streets et al. 2005). Volcanic eruptions are believed to be an important natural source of mercury (Clarkson and Magos 2006).

Methylmercury is a robust toxicant, and the primary target is the central nervous system (Clarkson and Magos 2006) especially the brain tissue (Clarkson et al. 2003). Methylmercury is highly mobile in the human body where its passage across the blood-brain and placental barriers, cause damage, both prenatally and postnatally (Tollefson and Cordle 1986). It appears to be most neurotoxic prenatally when the brain is developing rapidly (Myers and Davidson 2000). The journey of methylmercury into the human body is explained through the formation of water-soluble methylmercury complexes in body tissues that are attached to thiol groups in protein, certain peptides, and amino acids (Clarkson and Magos 2006). It may enter into body cells as methylmercury-cysteine complex and exit via glutathione pathway. The main route of its elimination from the body is via feces, which is as much as $90 \%$ of total excretion according to animal observation (Clarkson and Magos 2006). In adults, the main symptoms of methylmercury exposure related with intoxication are to the nervous system, with paraestesia or numbness in the hands and feet, coordination difficulties, and concentric constriction of the visual field, auditory symptoms, ischemic stroke, dementia and depression. It might also cause nephrotoxicity and gastrointestinal toxicity with ulceration and hemorrhage (CastroGonžalez and Mendez-Armenta 2008; Clarkson and Magos 2006; Tollefson and Cordle 1986).

Scientists worldwide have researched the toxicity of methylmercury since the first outbreak which was reported in Minamata, Japan, in 1956. Numerous reports and review articles discussing these issues were published. Among the earliest publications, as has been cited by Myers et al. (2000), were publications by the researchers from the University of Rochester on measurement of exposure and the consequences of exposure to various forms of mercury on experimental animals. Later, Swedish investigators discovered the methylation process of inorganic mercury by organisms in the aquatic sediments and in fish which may concentrate methylmercury either directly through the water or through components of the food chain (Myers et al. 2000). Recent scientific publications have focused on the levels of methylmercury contamination in seafood, namely, fish (Denton et al. 2006; Guerin et al. 2011; Ikem and Egiebor 2005; Mendil et al. 2010; Turkmen et al. 2005; Yilmaz et al. 2010), human exposure, and its related health effects (Burger 2009; Morgano et al. 2011; Castro-Gonžalez and Mendez-Armenta 2008; Myers and Davidson 2000).

There are few publications on the concentrations of mercury in marine fish reported by Malaysian researchers. Most studies reported on various levels of mercury in limited marine fish species that collected from selected sites in Peninsular Malaysia only. Among the most recent research studies were carried out by Alina et al. (2012), Mok et al. (2012), Kamaruzaman et al. (2011), Hajeb et al. (2009, 2010), Irwandi and Farida (2009), and Agusa et al. (2005a, 2007). Most of the results from these research studies showed that mercury were found to have lower concentrations in marine fish compared to the permissible limits set either by Malaysian Standards or JECFA guideline values. Only Agusa et al. (2005a) reported that some species of the marine fish captured from Malaysian markets had high mercury concentrations that may cause hazardous to the consumers. Similarly, Hajeb et al $(2009,2010)$ reported the highest level of mercury in longtail tuna and short-bodied mackerel captured from both east and west coast of Peninsular Malaysia. In another separated study, their findings showed high mercury intake by fishermen families at the rural areas compared to the general adult population (Hajeb et al 2011).

Studies from several neighboring areas/countries such as Gresik Coast, Indonesia (Soegianto et al. 2010), Mekong Delta, South Vietnam (Ikemoto et al. 2008), East Coast of 
Thailand (Cheevaporn et al 2000), Mekong River, and several places in Cambodia (Murphy et al. 2008; Agusa et al. 2005b) showed that variability of mercury concentrations was quite high from species to species of marine fish. Murphy et al. (2008) reported mercury levels of some fish species of up to sixfold higher compared to the average of $99 \mathrm{ng} / \mathrm{g}$ mercury in Kratie Mekong, Cambodia. Some marine fish species such as thresher shark, tille travelly, skipjack tuna, swordfish (Sompongchaiyakul et al. 2011), sharp-tooth snapper, and obtuse barracuda (Agusa et al. 2005b) had mercury concentrations exceeded the JECFA guidelines. All these research studies reported on few limited species of marine fish in selected locations for their studies only. Therefore, information on level of mercury in various marine fish consumed is timely. The objectives of this study were aimed at determining and interpreting the concentrations of total mercury in the edible tissues of 297 commonly consumed marine fish samples that composed of 46 species, collected in June to December 2009 from fish landing ports and wholesale markets throughout Peninsular Malaysia. This study will provide baseline data of mercury levels in muscle of 12 species of Carangidae, 11 species of Scrombidae, 5 species of Lutjanidae, 2 species of Latidae, 4 species of Dasyatidae, 4 species of Sciaenidae, and 8 species of Nemipteridae. The relationship between mercury levels and fish size (length and weight) was investigated, and mercury burden sampled from fish at different habitats, family group, and areas were also compared. It is hoped that later, the data reported will serve as an invaluable baseline study for estimating and assessing risk on mercury contamination through seafood consumption among Malaysians.

\section{Materials and methods}

Apparatus and reagent

Glassware and plastic containers were soaked in $2 \%$ nitric acid and left overnight before they were rinsed thoroughly with ultrapure water. All reagents used were of analytical grade. Ultrapure water was obtained from Elga, Ultra Pure Water System, Maxima.

\section{Sampling and sample preparation}

This was a cross-sectional descriptive study, and sample size for sampling of seafood is based on statistical calculation using prevalence of $48 \%$ of marine fish contaminated with mercury higher than the Malaysian guideline value (Agusa et al. 2005a). The formulation used was $N=\left(\left(\left(Z_{\alpha}{ }^{2} \mathrm{P}(1-\mathrm{P})\right) /\right.\right.$ $E^{2}$ ), where $Z=1.96$ (based on $95 \%$ cumulative interval (CI), $E=$ maximum tolerance error ( $5 \%$ ), and $\alpha=0.05$ at $95 \%$ CI. A minimum number of 383 seafood samples were required for analysis purposes. The selection of seafood were based the most popular/consumed seafood by local population identified from results of food dietary survey conducted among 3,500 subjects in Peninsular Malaysia (Nurul Izzah et al. unpublished results) (Table 1).

Samples were purchased from six selected major fish landing complexes of Fisheries Development Authority of Malaysia (LKIM) and from five wholesale wet markets throughout Peninsular Malaysia. Two fish landing complexes were in the west coast (at Port Klang and Mergong) while the other four complexes were located along the east coast of Peninsular Malaysia (at Kuala Besar, Pulau Kambing, Chendering, and Kuantan). The five major wholesale wet markets were located at Kampong Bakau, Bukit Mertajam, Kuala Pari, and Selayang, while Pandan was the only wet market located south of Peninsular Malaysia (Fig. 1). Seafood samples were collected from the first three fishing boats that landed at the LKIM complexes on the sampling day. At the wholesale wet markets, samples were collected from three randomly selected business units. Sampling was conducted from June to December 2009. A total of 394 seafood samples were collected during three successive visits to each location, and this paper reported results of mercury determination in marine fish samples only which consist of 297 number of samples.

Total length and weight of the fish samples were measured to the nearest millimeter and gram (Table 2). Fish samples were packed in polyethylene bags, labeled, and put into an icebox before they were transported to the laboratory. In the laboratory, the samples were kept frozen at $-21{ }^{\circ} \mathrm{C}$. For sample preparation, the fish samples were thawed at room temperature. The edible portion of fish was filleted, cut into small pieces, and homogenized. The homogenized muscles were then dried in the laboratory oven at $65^{\circ} \mathrm{C}$ to constant dry weight and ground using mortar.

The food items and feeding habits of both the pelagic and demersal fishes were referenced from the Global Information System on Fishes at the website: http://www.fishbase.us (Table 2). Most of the fish sampled in this study were classified as predatory, which live by killing and eating upon other fish or animals. Only five species (redtail scad, round scad, shortfin scad, Faughn's mackerel, and Indo-Pacific mackerel) that were captured in this study were non-predators. They fed on zooplankton, phytoplankton, and other plants. Information on tropic levels (TL) that expressed the position of a species in a marine food web was gathered from the same website. In the marine ecosystem, TL of consumers generally ranges between 2.0 for species feeding exclusively on plants or detritus and 5.5 for carnivores (Stergiou and Karpouzi 2002).

\section{Digestion procedures}

Samples for mercury analysis (including blanks) were digested in a microwave digestion system (Multiwave 3000-Anton Paar). Dried fish samples were weighed 
Table 1 Most preferred seafood by population of Peninsular Malaysia

\begin{tabular}{lll}
\hline No. & Types of seafood $^{\mathrm{a}}$ & Preference (\%) \\
\hline 1 & Indian mackerel & 70.9 \\
2 & Prawn/shrimp & 26.6 \\
3 & Yellowtail scad & 26.2 \\
4 & Black pomfret & 22.6 \\
5 & Tuna/kawakawa/bonito & 21.8 \\
6 & Squid/octopus & 21.3 \\
7 & Hairtail scad & 20.9 \\
8 & Spanish mackerel & 20.9 \\
9 & Red snapper & 14.7 \\
10 & Threadfin bream & 11.2 \\
11 & Stingray & 10.6 \\
12 & Freshwater catfish & 7.3 \\
13 & Barramundi & 7.2 \\
14 & Croaker & 5.4 \\
\hline
\end{tabular}

Identified from results of food dietary survey (3-day record) conducted among 3,500 subjects in Peninsular Malaysia (Nurul Izzah et al., unpublished results)

${ }^{\text {a }}$ Based on common name given by study subjects

accurately into the digestion vessels for $0.5 \mathrm{~g}$. A total of $5.0-\mathrm{ml}$ concentrated nitric acid and $2.0 \mathrm{ml}$ of hydrogen peroxide were added to each vessel. The vessels were sealed and placed into the rotor for microwave digestion. The power profile used for the digestion of samples with the Multiwave was as follows: During the first phase, the power of the digestion system was set at $600 \mathrm{~W}$, followed by 5-min ramping and holding, respectively. At the second phase, the power was increased to $1,400 \mathrm{~W}$ followed by 5-min ramping and 10-min holding time. Finally, at phase 3, the power was turned to zero with holding time of $15 \mathrm{~min}$. After the digestion process, samples with clear solutions were filtered through a $0.45-\mu \mathrm{m}$ acidresistant membrane. The solution was transferred to a $25-\mathrm{ml}$ volumetric flask and diluted with ultrapure water. The analytical reagent blanks were also prepared in the same manner but without the dried fish samples.

\section{Mercury analysis}

Mercury was analyzed by the cold vapor atomic absorption spectrometry (AAS) technique using the PerkinElmer Flow Injection Mercury System (FIMS) instrument equipped with FIMS-400 and a programmable sample dispenser following the method of Mohd Fairulnizal et al. (1998). Stock standard solution of mercury, $1,000 \mu \mathrm{g} / \mathrm{ml}$, was obtained from PerkinElmer. A sub-stock solution of $10 \mathrm{mg} / \mathrm{l}$ was prepared by dilution of the stock standard solution. The working standard solutions of $0,2,5$, and $10 \mu \mathrm{g} / 1$ were prepared by further dilution of the sub-stock solution. These working standards were prepared fresh daily. A linear range calibration method was used and the correlation coefficient was controlled at $r=$ 0.9995. Detection limit was based on the mercury concentration corresponding to three times the standard deviation of ten reagent blanks, which was $0.72 \mu \mathrm{g} / \mathrm{l}$. The analysis was validated by injecting of two different concentrations of mercury standard solutions utilized as quality control between each ten injection of samples, and the acceptable range was set between 85 and $110 \%$. Analytical control was accompanied by analysis of reagent blanks and standard reference samples (NIST SRM $^{\circledR} 1946$ - Lake Superior Fish Tissue). Average recovery of reference standards reached $90.7 \%$. The results were expressed in dry weight basis.

In order to compare the results with the national and international guidelines for the purpose of public health perspective, it was necessary to convert mercury concentrations in fish samples to a wet basis values using the formula: Dry weight concentration $=$ wet weight concentration $\times(100 / 100$ moisture percentage). The calculation for the amount of moisture content was calculated based on the works of Tee et al. (1997) and Nurnadia et al. (2011). The results were then grouped into five categories, following Chvojka et al. (1990) as cited by Al-Majed and Preston (2000). They described mercury in wet weight of fish from 0.05 to $0.15 \mu \mathrm{g} / \mathrm{g}$ as very low, $0.15-0.25 \mu \mathrm{g} / \mathrm{g}$ as low, $0.25-0.35 \mu \mathrm{g} / \mathrm{g}$ as medium, $0.35-$ $0.45 \mu \mathrm{g} / \mathrm{g}$ as high, and above $0.45 \mu \mathrm{g} / \mathrm{g}$ as very high. The recommended guideline levels by the joint FAO/WHO Expert Committee on Food Additives (FAO/WHO 2006) was set at $0.5 \mathrm{mg} / \mathrm{kg}$ methylmercury in fish. In Malaysia, under the Fourteenth Schedule of Regulation 38, Malaysian Food Regulation 1985 (Food Act 1983, (Act 281) and Regulations 2006), the maximum permitted proportion of methylmercury was set at the same level.

\section{Statistical analysis}

Data was cleaned and checked for discrepancies before analysis. The initial descriptive statistical analysis showed that the data was not normally distributed due to the existence of the outliers. Hence, non-parametric statistics were used. The medians, interquartile range, and percentile range were calculated using SPSS (version 11.5 for Windows, 2002, SPSS Inc.). The statistical significance of difference was assessed using MannWhitney's (MW) test for two groups and Kruskall-Wallis's (KW) test for three groups or more. The correlation coefficients were studied using Spearman correlation analysis. The level for significance was designated as $p<0.05$.

\section{Results}

A total of 297 samples that composed of 46 species of marine fish collected from selected major LKIM fish landing ports 
Fig. 1 Location map of sampling stations in states of Peninsular Malaysia

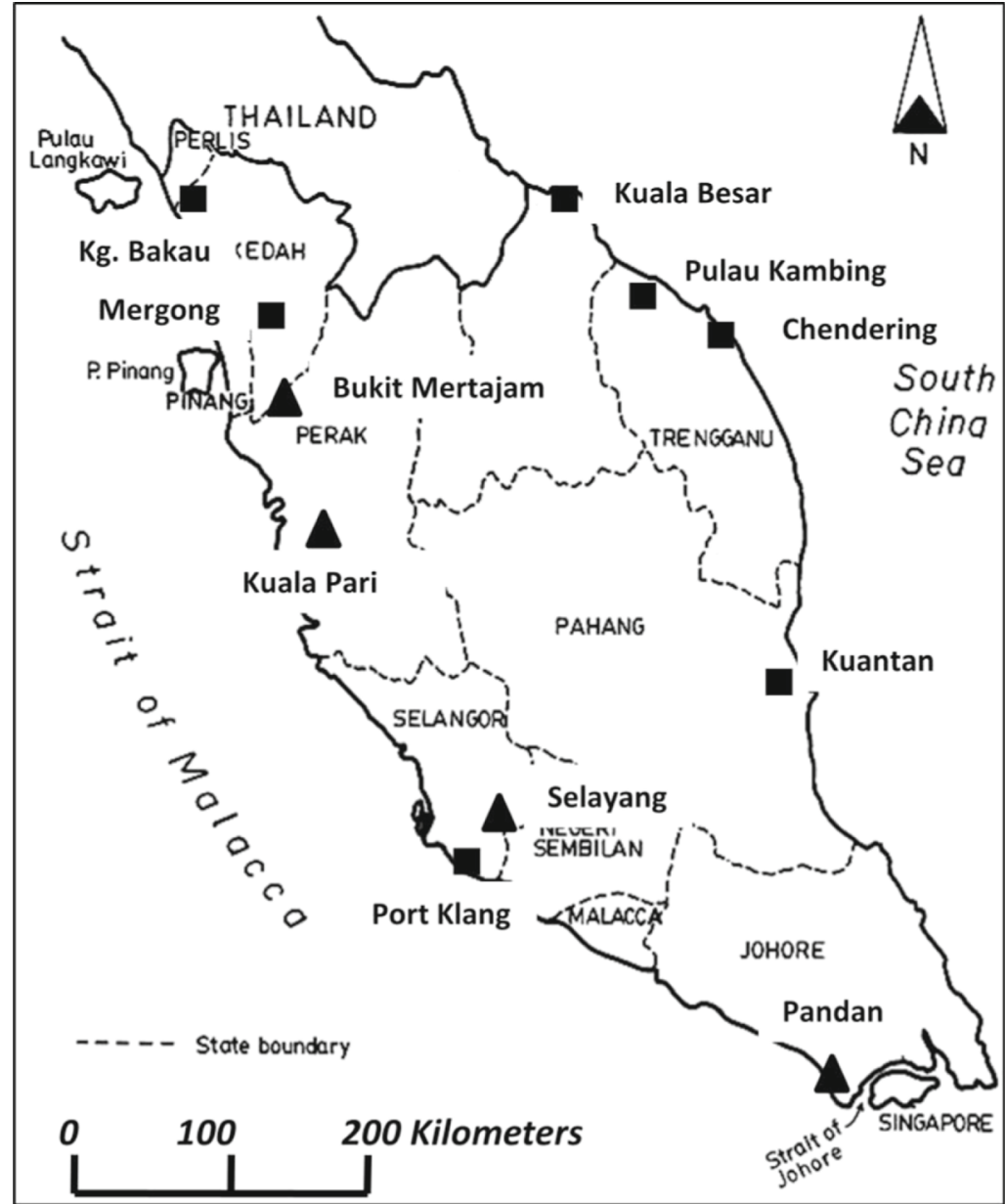

LKIM Complexes

Whole sale markets

Source: (C2010 Google-map data (C2010 MapIT, Tele Atlas,GMS. 14 May 2014.

and wholesale markets in Peninsular Malaysia are shown in Table 2. A number of 177 samples of pelagic fish were collected in this study. This group of fish live near the surface or in the water column of coastal and ocean. They were then classified into two different families: 80 of Carangidae and 97 of Scrombidae. The remaining 120 fish samples were demersal fish that live on or near the bottom of the sea or ocean. There were five families of demersal fish collected in this study, which were 24 of Lutjanidae, 15 of Latidae, 25 of Dasyatidae, 25 of Sciaenidae, and 31 of Nemipteridae.

The size of fish in the samples varied. The Carangidae, Sciaenidae, and Nemipteridae were small-sized fish with body length ranging from 12 to $30 \mathrm{~cm}$ and with weight of less than $0.5 \mathrm{~kg}$. Other family groups covered a relatively wide size range that composed of small, medium to large-sized fish; the smallest weighed $40 \mathrm{~g}$ and the largest $5 \mathrm{~kg}$. Generally, the larger fish were Spanish mackerels, tuna, red snapper, sea perch, and stingray.
The TL for fish captured in this study ranged from 2.7 to 4.5. More than half $(66.7 \%)$ of the samples had TL range from 3.7 to 4.5 , which indicated that most of the samples captured were carnivores or large pelagic. Another $32.3 \%$ had TL between 2.9 and 3.7 with a mean value of 3.4. This group was omnivorous that fed on a variety of prey. Only $1 \%$ of the samples fed on vegetable materials.

Total mercury levels in marine fish sampled from the fish landing ports and the wholesale markets in Peninsular Malaysia are summarized in Table 3. Mercury levels of 46 marine fish species ranged from 0.055 to $2.537 \mathrm{mg} / \mathrm{kg}$ of dry weight. Significant variations of mercury levels exist in different species $\left(\chi_{\mathrm{KW}}^{2}=103.581 ; p<0.001\right)$. Among pelagic fish, the median for mercury levels was higher $(>0.5 \mathrm{mg} / \mathrm{kg})$ in scad (Selar boops) and bonito (Sarda orientalis). While for the demersal fish, the highest mercury levels were shown in John's snapper (Lutjanus ruselli), mangrove red snapper (Lutjanus argentimaculatus), and doublewhip threadfin bream (Nemipterus nematophorus). Mercury levels were 
Table 2 List of most preferred marine fish collected form Fisheries Development Authority of Malaysia (LKIM) fish landing complexes and whole-sale market in Peninsular Malaysia

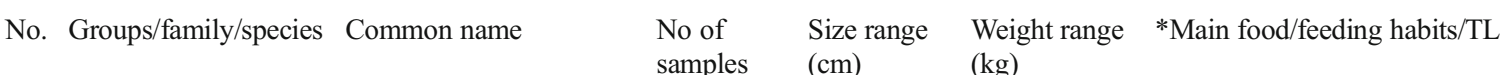

samples $\quad(\mathrm{cm}) \quad(\mathrm{kg})$

Pelagic fish

(a) Carangidae (80)

$1 \quad$ Selaroides leptolepis

2 Selar boops

Yellowstripe scad $\quad 13$

Oxeye scad

3 Selar crumenopthalmus

$4 \quad$ Atule mate

Bigeye scad

Yellowtail scad

Bigeye trevally

Caranx sexfasciatus
Seriola dumerili

Greater amberjack

Decapterus kurroides

Redtail scad

Decapterus muruadsi

Round scad

Decapterus russelli

Slender scad

Shortfin scad

10 Decapterus macrosoma

11 Megalaspis cordyla

Torpedo scad

12 Parastromateus niger Black pomfret

(b) Scrombidae (97)

14 Rastrelliger faughni

Faughn's mackerel

Indo-Pacific mackerel

15 Rastrelliger brachysoma

16 Scomber australasicus

17 Scomberomorus guttatus

18 Scomberomorus commerson

Blue mackerel

Indo-Pacific king mackerel

Narrowbarred Spanish mackerel

19 Gymnosarda unicolor Dogtooth tuna

20 Sarda orientalis

Striped bonito

21 Thunnus tonggol

Longtail tuna

22 Auxis thazard thazard Frigate tuna

23 Euthymus affinis

Kawakawa

Demersal fish

(c) Lutjanidae (24)

24 Lutjanus argentimaculatus

25 Lutjanus gibbus

26 Lutjanus sebae

27 Lutjanus malabaricus

28 Lutjanus russellii

(d) Latidae (15)

29 Lates calcarifer

30 Psammoperca waigiensis

(e) Dasyatidae (25)

31 Himantura gerrardi

32 Neotrygon kuhlii

Pale-edged stingray

(1)
Sharpnose stingray

Bluespotted stingray

Mangrove red snapper

Humpback red snapper

Emperor red snapper

Malabar blood snapper

John's snapper

Giant sea perch

Waigeu sea perch

4

7

5
$2.2-34.3$

$\begin{array}{ll}12.6-19.6 & 0.028-0.290 \\ 19.0-24.8 & 0.0090-0.212 \\ 23.8 & 0.186\end{array}$

23.1-26.3

22.7

19.6

18.5-26.8

18.1-36.2

16.5-30.1

$0.150-0.224$

0.140

0.106

0.066-0.224

$0.071-0.294$

$0.052-0.420$

\section{$-$}

$15.6-40.3$

$0.082-1.466$

13.4-24.3

$0.200-0.360$

19.0-21.8

$16.6-25.5$

0.100-0.180

$0.050-0.280$

17.0-22.4

$0.040-0.152$

29.6-55.5

0.176-1.066

$40.1-85.5$

$0.394-4.550$

$19.8-49.5$

0.082-5.000

25.5-48.0

0.232-1.600

17.2-50.0

$0.082-1.733$

29.6-31.2

0.334-0.412

29.4-69.3

$0.370-4.733$

\section{$38.3-38.5$}

1.033-1.175

20.2

18.1-62.0

0.148

27.9-49.75

0.102-3.300

66.0

0.394-1.175

4.050

26.6-71.6

$0.046-4.650$

$34.6-38.3$

$0.396-0.875$

$21.4-116.3 \quad 0.208-2.880$

$45.7-114.0 \quad 0.510-4.300$

$40.7-147.3 \quad 0.188-1.157$
Nekton, zooplankton, zoobenthos/predator/3.5

Zooplankton, zoobenthos/variables/3.5

Nekton, zooplankton, zoobenthos, detritus/ predators $/ 4.1$

Nekton, zooplankton, zoobenthos, plants/ predators $/ 4.5$

Nekton/predators/4.5

Nekton, zooplankton, zoobenthos/predators/4.5

Zooplankton/3.4

Zooplankton/3.4

Nekton, zooplankton, plants zoobenthos/ variables $/ 3.7$

Zooplankton/3.4

Nekton, zooplankton, zoobenthos, plants detritus/ predators $/ 4.4$

Plants, zooplankton, zoobenthos/2.9

Nekton, zooplankton, zoobenthos, plants detritus/ predators $/ 3.2$

Zooplankton/3.4

Zooplankton, plants/2.7

Nekton, zooplankton, zoobenthos/predators $/ 4.2$

Nekton, zoobenthos/predators/4.3

Nekton, zooplankton, zoobenthos/predator/4.5

Nekton/predator/4.5

Nekton, zoobenthos/predator $/ 4.2$

Nekton, zoobenthos/predator/4.5

Nekton, zoobenthos/predator/4.3

Nekton, zoobenthos/predator/4.5

Nekton, zooplankton, zoobenthos/predator/3.6

Nekton, zoobenthos/predator/3.6

Nekton, zooplankton, zoobenthos/predator/4.3

Nekton, zoobenthos/predator/4.5

Detritus, nekton, zoobenthos/predator/4.3

Nekton, zooplankton, zoobenthos/predator/4.4

Nekton, zoobenthos/predator/4.0

Zoobenthos/predator $/ 3.7$

Nekton, zoobenthos/3.2

Zoobenthos/predator/3.5 
Table 2 (continued)

\begin{tabular}{|c|c|c|c|c|c|c|}
\hline No. & Groups/family/species & Common name & $\begin{array}{l}\text { No of } \\
\text { samples }\end{array}$ & $\begin{array}{l}\text { Size range } \\
(\mathrm{cm})\end{array}$ & $\begin{array}{l}\text { Weight range } \\
(\mathrm{kg})\end{array}$ & *Main food/feeding habits/TL \\
\hline 34 & $\begin{array}{l}\text { Himantura uarnak } \\
\text { (f) Sciaenidae (25) }\end{array}$ & Honeycomb stingray & 3 & $\begin{array}{r}131.6- \\
142.0\end{array}$ & $2.266-3.040$ & Nekton, zoobenthos/predator/3.6 \\
\hline 35 & Chrysochir aureus & Reeve's croaker & 3 & $19.0-25.4$ & $0.074-0.220$ & Zoobenthos/predator/3.5 \\
\hline 36 & Otolithoides ruber & Tigertooth croaker & 6 & $13.0-24.2$ & $0.04-0.113$ & Zoobenthos/predator/3.6 \\
\hline 37 & Nibea soldado & Soldier croaker & 15 & $15.3-21.6$ & $0.041-0.274$ & Zoobenthos, nekton/predator $/ 4.0$ \\
\hline 38 & $\begin{array}{l}\text { Otolithoides biauritus } \\
\text { (g) Nemipteridae (31) }\end{array}$ & Bronze croaker & 1 & 20.9 & 0.132 & Zoobenthos, nekton/predator/4.1 \\
\hline 39 & Nemipterus bathybius & $\begin{array}{l}\text { Yellowbelly threadfin } \\
\text { bream }\end{array}$ & 6 & $15.7-33.7$ & $0.063-0.516$ & Zoobenthos, nekton/predator $/ 4.0$ \\
\hline 40 & Nemipterus japonicus & Japanese threadfin bream & 11 & $16.9-29.2$ & $0.063-0.212$ & Zoobenthos, nekton/predator $/ 3.8$ \\
\hline 41 & Nemipterus furcosus & Forktail threadfin bream & 3 & $18.2-21.4$ & $0.102-0.162$ & Zoobenthos, nekton/predator/3.6 \\
\hline 42 & $\begin{array}{l}\text { Nemipterus } \\
\text { thosaporni }\end{array}$ & Threadfin bream & 4 & $17.0-24.0$ & $0.059-0.210$ & Not available/3.7 \\
\hline 43 & $\begin{array}{l}\text { Nemipterus } \\
\text { tambuloides }\end{array}$ & Fivelined threadfin bream & 2 & $17.5-21.4$ & $0.086-0.109$ & Zoobenthos, nekton/predator/4.0 \\
\hline 44 & $\begin{array}{l}\text { Nemipterus } \\
\text { nematophorus }\end{array}$ & $\begin{array}{l}\text { Doublewhip threadfin } \\
\text { bream }\end{array}$ & 2 & $16.1-25.6$ & $0.058-0.154$ & Not available/3.7 \\
\hline 45 & $\begin{array}{l}\text { Nemipterus } \\
\quad \text { marginatus }\end{array}$ & $\begin{array}{l}\text { Red filament threadfin } \\
\text { bream }\end{array}$ & 2 & $23.0-25.5$ & $0.110-0.240$ & Zoobenthos/predator/3.5 \\
\hline 46 & Nemipterus nemurus & Redspine threadfin bream & 1 & 17.8 & 0.096 & Zoobenthos, nekton/predator/4.0 \\
\hline
\end{tabular}

Source: http://www.fishbase.us. Nekton — the division of the pelagic population that comprises of the free-swimming animals. They are capable of withstanding the force of the ocean current and are able to travel over long distances. Fish, squids, cetaceans, pinnipeds, sea snakes, turtles, and penguins constitute the nekton group. Zooplankton - animal constituent of plankton; mainly small crustaceans and fish larvae. Free-swimming aquatic animals, essentially independent of water movements. Zoobenthos - the invertebrate animals that live in or on the seabed, including the intertidal zone. Plants - phytoplankton and other plants. Detritus - non-living particulate organic material (as opposed to dissolved organic material). It typically includes the bodies or fragments of dead organisms as well as fecal material

Tropic levels (TLs):

2.0-2.1 (mean 2.02) - pure herbivores

$2.1<\mathrm{TL}<2.9$ (mean 2.5) - omnivores with a preference for vegetable material

$2.9<\mathrm{TL}<3.7$ (mean 3.4) - omnivores with a preference for animal material (feeding on a variety of prey)

$3.7<\mathrm{TL}<4.0$ (mean 3.85) — carnivores with a preference for decapods and fish

$4.0<\mathrm{TL}<4.5$ (mean 4.32) - carnivores with a preference for fish cephalopods

(Stergiou and Karpouzi 2002)

significantly higher in higher tropic level fish $\left(\chi_{\mathrm{KW}}^{2}=7.787\right.$; $p<0.02$ ).

The median of mercury levels for demersal fish $(0.460 \pm$ $0.414 \mathrm{mg} / \mathrm{kg}$ dry weight $)$ was significantly higher $\left(\chi_{\mathrm{MW}}^{2}=\right.$ $5401.0 ; p<0.001)$ compared to the pelagic fish $(0.292 \pm$ $0.169 \mathrm{mg} / \mathrm{kg}$ of dry weight) (Table 4). Mercury level was significantly lower $\left(\chi_{\mathrm{KW}}^{2}=7.787 ; p<0.02\right)$ in herbivorous when compared to the omnivorous and carnivorous fish. Among the family groups, mercury levels were significantly higher $\left(\chi_{\mathrm{KW}}^{2}=46.122 ; p<0.001\right)$ in Latidae, followed by Dasyatidae, Lutjanidae, and Nemipteridae. No significant differences $\left(\chi_{\mathrm{MW}}^{2}=1,863.0 ; p=0.274\right)$ were shown for mercury levels between local and imported fish, different coastal regions (west, east, and south) $\left(\chi_{\mathrm{KW}}^{2}=679.0 ; p=0.712\right)$, and sampling points (fish landing ports and wet markets) $\left(\chi_{\mathrm{MW}}^{2}=\right.$ $10,114.0 ; p=0.738)$. However, mercury levels in marine fish sampled from different sampling locations showed significant differences at $p=0.014\left(\chi_{\mathrm{KW}}^{2}=22.263\right)$. Higher mercury levels were found in fish sampled from Port Klang $(0.563 \pm$ $0.509 \mathrm{mg} / \mathrm{kg}$ of dry weight), Kuala Besar $(0.521 \pm 0.415 \mathrm{mg} / \mathrm{kg}$ of dry weight), and Pandan $(0.380 \pm 0.481 \mathrm{mg} / \mathrm{kg}$ dry weight $)$ compared to other locations. Mercury levels in bigger fish were significantly higher $\left(\chi_{\mathrm{MW}}^{2}=6,642.0 ; p=0.002\right)$ compared to the smaller ones. Scatter plots (Fig. 2) showed that mercury levels were positively correlated with weight and length of the fish, with significant Spearman correlation coefficients of 0.237 and 0.297 , respectively.

The distribution of total mercury in fish based on categories by Chvojka et al. (1990) is shown in Fig. 3. The results from this study indicated that most of the samples $(83.7 \%)$ had very low levels of mercury followed by $10.1 \%$ with low mercury levels. Another $4.2 \%$ of the samples had medium levels of 
Table 3 Total mercury levels in marine fish sampled from the LKIM complexes and wholesale market in Peninsular Malaysia

\begin{tabular}{|c|c|c|c|c|c|c|c|c|}
\hline \multirow[t]{2}{*}{ No. } & \multirow[t]{2}{*}{ Groups/family/species } & \multirow[t]{2}{*}{ Common name } & \multirow[t]{2}{*}{ Number } & \multicolumn{5}{|c|}{ Total mercury (mg/kg dry weight (DW)) } \\
\hline & & & & Median & IQR & Min & Max & Range \\
\hline & Pelagic fish & & & & & & & \\
\hline & Carangidae (80) & & & & & & & \\
\hline 1 & Selaroides leptolepis & Yellowstripe scad & 13 & 0.252 & 0.125 & 0.138 & 2.137 & 1.999 \\
\hline 2 & Selar boops & Oxeye scad & 3 & 0.555 & - & 0.305 & 0.719 & 0.414 \\
\hline 3 & Selar crumenopthalmus & Bigeye scad & 1 & 0.298 & - & - & - & - \\
\hline 4 & Atule mate & Yellowtail scad & 4 & 0.458 & 0.304 & 0.371 & 0.746 & 0.375 \\
\hline 5 & Caranx sexfasciatus & Bigeye trevally & 1 & 0.293 & - & - & - & - \\
\hline 6 & Seriola dumerili & Greater amberjack & 1 & 0.203 & - & - & - & - \\
\hline 7 & Decapterus kurroides & Redtail scad & 4 & 0.272 & 0.263 & 0.186 & 0.535 & 0.349 \\
\hline 8 & Decapterus muruadsi & Round scad & 7 & 0.317 & 0.171 & 0.173 & 0.535 & 0.362 \\
\hline 9 & Decapterus russelli & Slender scad & 10 & 0.195 & 0.108 & 0.078 & 0.304 & 0.226 \\
\hline 10 & Decapterus macrosoma & Shortfin scad & 1 & 0.354 & - & - & - & - \\
\hline 11 & Megalaspis cordyla & Torpedo scad & 20 & 0.319 & 0.198 & 0.202 & 0.913 & 0.711 \\
\hline \multirow[t]{3}{*}{12} & Parastromateus niger & Black pomfret & 15 & 0.242 & 0.121 & 0.158 & 0.518 & 0.360 \\
\hline & & Total & 80 & 0.291 & 0.153 & 0.078 & 2.137 & 2.059 \\
\hline & Scrombidae (97) & & & & & & & \\
\hline 13 & Rastrelliger kanagurta & Indian mackerel & 13 & 0.180 & 0.066 & 0.055 & 0.454 & 0.399 \\
\hline 14 & Rastrelliger faughni & Faughn's mackerel & 6 & 0.357 & 0.246 & 0.254 & 0.753 & 0.499 \\
\hline 15 & Rastrelliger brachysoma & Indo-Pacific mackerel & 3 & 0.261 & - & 0.258 & 0.332 & 0.074 \\
\hline 16 & Scomber australasicus & Blue mackerel & 18 & 0.269 & 0.065 & 0.152 & 0.610 & 0.458 \\
\hline 17 & Scomberomorus guttatus & Indo-Pacific king mackerel & 12 & 0.262 & 0.355 & 0.159 & 0.983 & 0.824 \\
\hline 18 & Scomberomorus commerson & Narrowbarred Spanish mackerel & 14 & 0.368 & 0.953 & 0.153 & 1.378 & 1.226 \\
\hline 19 & Gymnosarda unicolor & Dogtooth tuna & 10 & 0.342 & 0.456 & 0.216 & 1.518 & 1.302 \\
\hline 20 & Sarda orientalis & striped bonito & 6 & 0.543 & 1.048 & 0.200 & 0.179 & 1.592 \\
\hline 21 & Thunnus tonggol & Longtail tuna & 8 & 0.358 & 0.173 & 0.178 & 0.565 & 0.387 \\
\hline 22 & Auxis thazard thazard & Frigate tuna & 2 & 0.237 & - & 0.207 & 0.266 & 0.059 \\
\hline \multirow[t]{4}{*}{23} & Euthymus affinis & Kawakawa & 5 & 0.289 & - & 0.226 & 0.322 & 0.096 \\
\hline & & Total & 97 & 0.293 & 0.190 & 0.055 & 1.792 & 1.737 \\
\hline & Demersal fish & & & & & & & \\
\hline & Lutjanidae (24) & & & & & & & \\
\hline 24 & Lutjanus argentimaculatus & Mangrove red snapper & 3 & 0.856 & - & 0.317 & 0.950 & 0.633 \\
\hline 25 & Lutjanus gibbus & Humpback red snapper & 1 & 0.436 & - & - & - & - \\
\hline 26 & Lutjanus sebae & Emperor red snapper & 11 & 0.334 & 0.516 & 0.173 & 1.810 & 1.637 \\
\hline 27 & Lutjanus malabaricus & Malabar blood snapper & 5 & 0.413 & 0.366 & 0.290 & 0.723 & 0.433 \\
\hline \multirow[t]{3}{*}{28} & Lutjanus russellii & John's snapper & 4 & 1.366 & - & - & - & - \\
\hline & & Total & 24 & 0.465 & 0.566 & 0.173 & 2.666 & 2.493 \\
\hline & Latidae (15) & & & & & & & \\
\hline 29 & Lates calcarifer & Giant sea perch & 11 & 0.537 & 0.436 & 0.255 & 1.408 & 1.153 \\
\hline \multirow[t]{3}{*}{30} & Psammoperca waigiensis & Waigeu sea perch & 4 & 0.532 & 0.165 & 0.398 & 0.601 & 0.203 \\
\hline & & Total & 15 & 0.537 & 0.267 & 0.255 & 1.408 & 1.153 \\
\hline & Dasyatidae (25) & & & & & & & \\
\hline 31 & Himantura gerrardi & Sharpnose stingray & 10 & 0.384 & 0.741 & 0.206 & 1.432 & 1.226 \\
\hline 32 & Neotrygon kuhlii & Bluespotted stingray & 7 & 0.492 & 1.251 & 0.226 & 2.537 & 2.311 \\
\hline 33 & Dasyatis zugei & Pale-edged stingray & 5 & 0.548 & 0.509 & 0.233 & 0.905 & 0.672 \\
\hline \multirow[t]{2}{*}{34} & Himantura uarnak & Honeycomb stingray & 3 & 0.425 & - & 0.204 & 2.517 & 2.313 \\
\hline & & Total & 25 & 0.492 & 0.740 & 0.204 & 2.537 & 2.333 \\
\hline
\end{tabular}

Sciaenidae (25) 
Table 3 (continued)

\begin{tabular}{|c|c|c|c|c|c|c|c|c|}
\hline \multirow[t]{2}{*}{ No. } & \multirow[t]{2}{*}{ Groups/family/species } & \multirow[t]{2}{*}{ Common name } & \multirow[t]{2}{*}{ Number } & \multicolumn{5}{|c|}{ Total mercury (mg/kg dry weight (DW)) } \\
\hline & & & & Median & IQR & Min & Max & Range \\
\hline 35 & Chrysochir aureus & Reeve's croaker & 3 & 0.498 & - & 0.282 & 0.733 & 0.451 \\
\hline 36 & Otolithoides ruber & Tigertooth croaker & 6 & 0.421 & 0.423 & 0.283 & 0.775 & 0.492 \\
\hline 37 & Nibea soldado & Soldier croaker & 15 & 0.424 & 0.132 & 0.181 & 1.227 & 1.046 \\
\hline \multirow[t]{3}{*}{38} & Otolithoides biauritus & Bronze croaker & 1 & 0.069 & - & - & - & - \\
\hline & & Total & 25 & 0.424 & 0.217 & 0.069 & 1.227 & 1.158 \\
\hline & Nemipteridae (31) & & & & & & & \\
\hline 39 & Nemipterus bathybius & Yellowbelly threadfin bream & 6 & 0.383 & 0.328 & 0.263 & 0.753 & 0.490 \\
\hline 40 & Nemipterus japonicus & Japanese threadfin bream & 11 & 0.464 & 0.724 & 0.213 & 1.206 & 0.993 \\
\hline 41 & Nemipterus furcosus & Forktail threadfin bream & 3 & 0.642 & - & 0.371 & 0.918 & 0.547 \\
\hline 42 & Nemipterus thosaporni & Threadfin bream & 4 & 0.570 & 0.659 & 0.402 & 1.244 & 0.842 \\
\hline 43 & Nemipterus tambuloides & Fivelined threadfin bream & 2 & 0.426 & - & 0.397 & 0.454 & 0.057 \\
\hline 44 & Nemipterus nematophorus & Doublewhip threadfin bream & 2 & 1.211 & - & 0.858 & 1.563 & 0.704 \\
\hline 45 & Nemipterus marginatus & Red filament threadfin bream & 2 & 0.244 & - & 0.207 & 0.281 & 0.074 \\
\hline \multirow[t]{2}{*}{46} & Nemipterus nemurus & Redspine threadfin bream & 1 & 0.298 & - & - & - & - \\
\hline & & Total & 31 & 0.454 & 0.459 & 0.207 & 1.563 & 1.356 \\
\hline
\end{tabular}

Comparison of mercury levels for different fish species: $\chi_{\mathrm{KW}}^{2}=109.596, p=0.000$

$I Q R$ interquartile range

mercury, and $1 \%$ had high levels. Only $1 \%$ or three samples of bluespotted stingray (Neotrygon kuhlii), honeycomb stingray (Himantura uarnak), and John's snapper (Lutjanus ruselli) had very high mercury levels. The latter two samples exceeded the guidelines of $0.5 \mathrm{mg} / \mathrm{kg}$. However, considering that $95 \%$ or more of total mercury in the edible portions of fish and other seafood is in the form of methylmercury ( $\mathrm{Li}$ et al. 2009; Khaniki et al. 2005), only one sample (median mercury level in Lutjanus ruselli, $0.5012 \mathrm{mg} / \mathrm{kg}$ ) exceeded the guidelines. None of the samples exceeded the guidelines if the ratio of methylmercury to total mercury ranged from 70 to $83 \%$ were considered (Hajeb et al. 2010).

Based on the five categories, this study has also identified few samples of fish with high mercury levels, two samples of tuna (S. orientalis and Gymnosarda unicolor) and one sample of yellowstripe scad (Selaroides leptolepis). For medium levels, one sample of snapper (Lutjanus sebae), four samples of narrow-barred Spanish mackerel (Scomberomorus commerson), one sample of barramundi (Lates calcarifer), two samples of stingray (Himantura gerrardi and Neotrygon kuhlii), two samples of tuna (G. unicolor and S. orientalis), and one sample of each thread-fin bream ( $N$. nematophorus) and soldier croaker (S. orientalis).

\section{Discussion}

The present study provides data on total mercury levels in marine fish tissue sampled from both the fish landing ports and the wholesale wet markets throughout Peninsular Malaysia. This study has several advantages whereby mercury was determined in a wide range of fish species (46 marine fish species) captured from the different geographical areas over different periods, with three visits for each sampling location within a 6-month time (from June to December 2009). Several interesting findings can be reached from this study: The data indicated that mercury levels differed significantly among the different families and species of fish. It also showed that mercury were found to be significantly higher in omnivorous and carnivorous food feeding fish compared to the herbivorous. The mercury levels were also significantly higher in demersal fish when compared to the pelagic fish. Fish captured from highly anthropogenic activity areas showed higher mercury level, and positive correlation were shown between mercury concentrations with fish size. Each of these factors was discussed below.

The results from this study concurred with other Malaysian studies (Table 5), in that most of the mercury levels in different species of fish were lower than the national and international permissible limits. Hajeb et al. (2009) reported comparable results of mercury levels in Indo-Pacific mackerel $(0.45 \pm$ $0.056 \mu \mathrm{g} / \mathrm{g}$ dry weight $(\mathrm{DW}))$, black pomfret $(0.13 \pm$ $0.15 \mu \mathrm{g} / \mathrm{g} \mathrm{DW})$, and longtail tuna $(0.5 \pm 0.71 \mu \mathrm{g} / \mathrm{g} \mathrm{DW})$ as compared to this study. However, they reported lower mercury levels for narrow-barred Spanish mackerel $(0.04 \pm 0.02 \mu \mathrm{g} / \mathrm{g}$ DW), giant perch $(0.10 \pm 0.06 \mu \mathrm{g} / \mathrm{g} \mathrm{DW})$, and sardines $(0.00 \pm$ $0.02 \mu \mathrm{g} / \mathrm{g} \mathrm{DW}$ ). Later, they reported extremely higher mercury levels in Rastrelliger brachysoma $(0.229-0.778 \mu \mathrm{g} / \mathrm{g} \mathrm{WW})$ 
Table 4 Comparison of mercury levels in marine fish collected from Peninsular Malaysia at different factors
Kruskal-Wallis (KW) and MannWhitney (MW) $U$ test were applied

$I Q R$ interquartile range

\begin{tabular}{|c|c|c|c|c|}
\hline No. & Factors & Number & Median (IQR) & $\left(\chi^{2}\right) p$ value \\
\hline \multirow[t]{3}{*}{1} & Habitats & & & \multirow{3}{*}{$\mathrm{MW}_{5401.0}(0.000)$} \\
\hline & Pelagic & 170 & $0.292(0.169)$ & \\
\hline & Demersal & 118 & $0.460(0.414)$ & \\
\hline \multirow[t]{4}{*}{2} & Feeding habits & & & \multirow{4}{*}{$\mathrm{KW}_{7.787(0.020)}$} \\
\hline & Herbivorous & 19 & $0.258(0.118)$ & \\
\hline & Omnivorous & 109 & $0.334(0.322)$ & \\
\hline & Carnivorous & 160 & $0.354(0.250)$ & \\
\hline \multirow[t]{8}{*}{3} & Family group & & & \multirow{8}{*}{$\mathrm{KW}_{46.122(0.000)}$} \\
\hline & Carangidae & 79 & $0.291(0.153)$ & \\
\hline & Scrombidae & 91 & $0.293(0.190)$ & \\
\hline & Lutjanidae & 22 & $0.465(0.566)$ & \\
\hline & Latidae & 15 & $0.537(0.267)$ & \\
\hline & Dasyatidae & 25 & $0.492(0.740)$ & \\
\hline & Sciaenidae & 25 & $0.424(0.217)$ & \\
\hline & Nemipteridae & 31 & $0.454(0.459)$ & \\
\hline \multirow[t]{3}{*}{4} & Origins & & & \multirow{3}{*}{$\mathrm{MW}_{1863.0}(0.274)$} \\
\hline & Local & 231 & $0.332(0.275)$ & \\
\hline & Import & 19 & $0.359(0.237)$ & \\
\hline \multirow[t]{4}{*}{5} & Coastal & & & \multirow{4}{*}{${ }^{\mathrm{KW}} 0.679(0.712)$} \\
\hline & West coast & 97 & $0.330(0.255)$ & \\
\hline & East coast & 158 & $0.333(0.272)$ & \\
\hline & South & 33 & $0.380(0.481)$ & \\
\hline \multirow[t]{3}{*}{6} & Sampling points & & & \multirow{3}{*}{$\mathrm{MW}_{10114.0}(0.738)$} \\
\hline & LKIM fish landing complexes & 150 & $0.354(0.298)$ & \\
\hline & Wholesale wet market & 138 & $0.334(0.263)$ & \\
\hline \multirow[t]{12}{*}{7} & Sampling locations & & & \multirow{12}{*}{$\mathrm{KW}_{22.263(0.014)}$} \\
\hline & Selayang & 25 & $0.295(0.253)$ & \\
\hline & Klang & 20 & $0.563(0.509)$ & \\
\hline & Kuala Pari & 37 & $0.356(0.292)$ & \\
\hline & Bukit Mertajam & 14 & $0.348(0.156)$ & \\
\hline & Kuala Perlis & 29 & $0.306(0.185)$ & \\
\hline & Mergong & 33 & $0.320(0.188)$ & \\
\hline & Kuala Besar & 20 & $0.521(0.415)$ & \\
\hline & Pandan & 33 & $0.380(0.481)$ & \\
\hline & Kuantan & 36 & $0.301(0.142)$ & \\
\hline & Chendering & 15 & $0.285(0.142)$ & \\
\hline & Pulau Kambing & 26 & $0.321(0.222)$ & \\
\hline \multirow[t]{3}{*}{8} & Body length of fish & & & \multirow{3}{*}{${ }^{\mathrm{MW}} 6642.0(0.002)$} \\
\hline & Body length $<20 \mathrm{~cm}$ & 92 & $0.311(0.223)$ & \\
\hline & Body length $\geq 20 \mathrm{~cm}$ & 187 & $0.354(0.306)$ & \\
\hline
\end{tabular}

and Thunnus tonggol (0.225-0.914 $\mu \mathrm{g} / \mathrm{g}$ WW) compared to this study (Hajeb et al. 2010). Results from Kamaruzaman et al. (2011) showed that the mercury levels were ten times lower in Nemipterus japonicas $(0.012 \pm 0.008 \mu \mathrm{g} / \mathrm{g} \mathrm{DW})$, L. sebae $(0.015 \pm 0.001 \mu \mathrm{g} / \mathrm{g} \mathrm{DW})$, and Otolithes ruber $(0.017 \pm 0.003 \mu \mathrm{g} / \mathrm{g} \mathrm{DW})$ compared to this current study. Alina et al. (2012) reported much lower results of mercury levels in
Japanese threadfin bream $(0.004-0.0065 \mu \mathrm{g} / \mathrm{g}$ wet weight (WW)), Malabar red snapper (0.0021-0.0054 $\mu \mathrm{g} / \mathrm{g}$ WW), Spanish mackerel $(0.002-0.0022 \mu \mathrm{g} / \mathrm{g} W W)$, and Indian mackerel $(0.001-0.0011 \mu \mathrm{g} / \mathrm{g} \mathrm{WW})$. They also found that the mercury levels in pelagic fish were lower than the levels in demersal fish. Mercury level in Nemipterus furcosus is relatively higher in this study $(0.642 \mu \mathrm{g} / \mathrm{g} \mathrm{DW})$, and the 

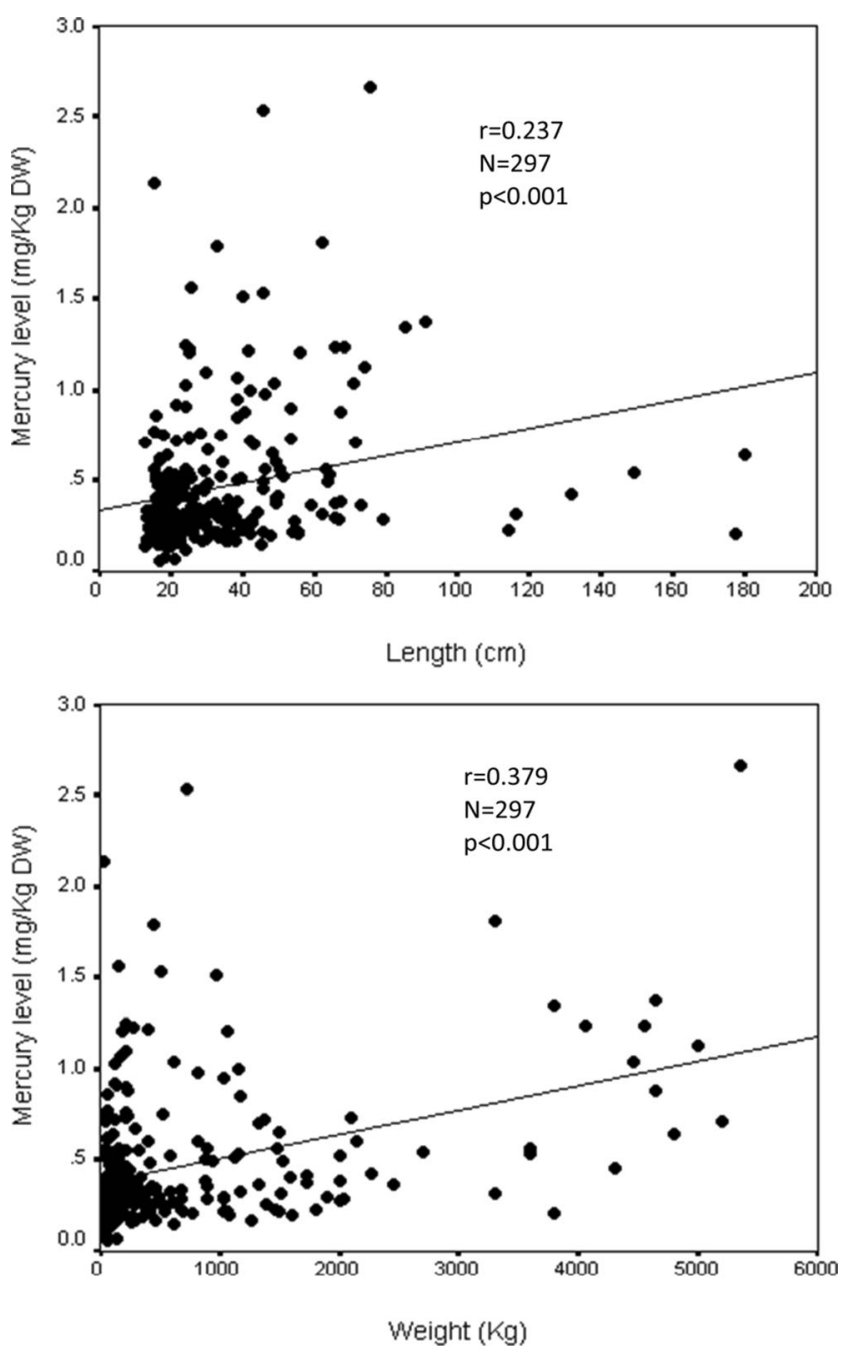

Fig. 2 Relationship between total mercury levels (mg/kg dry weight), length, and weight of marine fish samples from Peninsular Malaysia

results are similar as reported by Agusa et al. (2007) $(0.67 \mu \mathrm{g} /$ g DW). They also reported similar results for Torpedo scad $(0.21-0.27 \mu \mathrm{g} / \mathrm{g}$ DW) and bigeye scad (0.11-0.36 $\mu \mathrm{g} / \mathrm{g}$ DW). None of these previous studies reported on the mercury levels in $N$. nematophorus, whereas in this study, the level was among the highest for family Nemipteridae. Nevertheless, only two samples were captured in this study (Table 3).

Total mercury median concentrations varied significantly $(p<0.05)$ among different fish species tested. Mercury accumulates into fish tissue through the food chain whereby it transfers between aquatic plants and aquatic animals, from sediment, as well as from the water environments (Bidone et al. 1997). Methylmercury is a major fraction of total mercury concentrations accumulated into fish tissue where it ranges from 85 to $97 \%$ (Bidone et al. 1997). Highest percentage of mercury as methylmercury in ray species was found in muscle tissue and accounting to nearly $100 \%$ of mercury present as methylmercury (Horvat et al. 2014). The indirect bioaccumulation process is a phenomena in which a mercury substance accumulates into fish tissue based on its tropic level in a food chain (Bidone et al. 1997). The variability of fish food is based on their habitat, which may be demersal, benthopelagic, pelagic, bathy-demersal, and reef-associated with fish living and feeding on or near coral reefs (Stergiou and Karpouzi 2005). Tropic level expresses the position of a species in the marine food web, and its estimation requires knowledge of what each species feeds on and in what quantities (Stergiou and Karpouzi 2005). Briefly, mercury enters the food chain via phytoplankton and then accumulated as methylmercury by other links in the chain, via tropic transfer (Seixas et al. 2013).

Carnivorous species are placed at higher tropic level than non-carnivorous species in a food chain (Bidone et al. 1997; Stergiou and Karpouzi 2005). These groups of fish live and feed in the open sea and are associated with the surface or middle depths of a body of water; they are free-swimming in the seas, oceans, or open waters, and they were not associated with the bottom (Stergiou and Karpouzi 2005). It is well known that mercury concentrations in carnivorous fish with higher tropic level are higher than in herbivores, omnivores, or planktivores (Burger et al. 2001; Burger and Gochfeld 2011; Liu et al. 2014). Yet, mercury concentration in top-level predators had the highest levels compared to the bottomdwelling fish (Burger and Gochfeld 2011). Findings from this
Fig. 3 The distribution of total mercury in fish based on categories by Chvojka et al. (1990) in their study: mercury in snapper from the New South Wales Coast, Australia. These categories were cited by AlMajed and Preston (2000) in their study of mercury content in zooplankton and fish tissue collected from Kuwait Territorial Waters

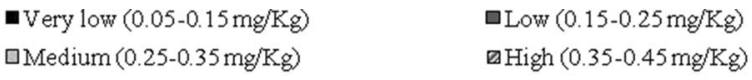

- Very low $(0.05-0.15 \mathrm{mg} / \mathrm{Kg})$ 口Medium $(0.25-0.35 \mathrm{mg} / \mathrm{Kg})$ a High $(0.35-0.45 \mathrm{mg} / \mathrm{Kg})$ EVery high (above $0.45 \mathrm{mg} / \mathrm{Kg}$ )

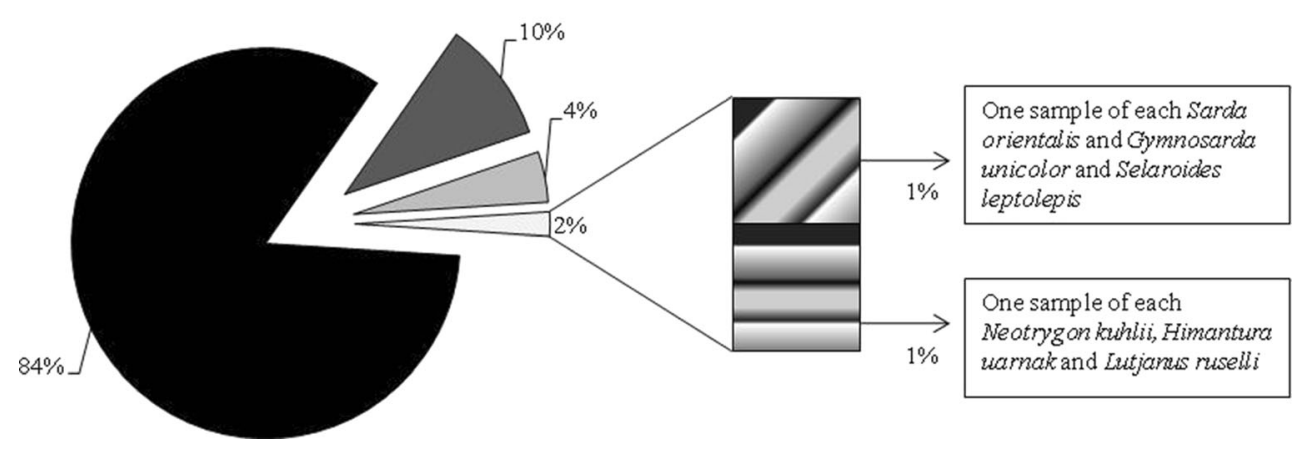


Table 5 Recent publications of mercury analysis in marine fish in Malaysia

\begin{tabular}{|c|c|c|c|}
\hline Sampling locations & Species and no. of samples & Significant findings & References \\
\hline $\begin{array}{l}\text { Retail outlet in Selangor and fishes } \\
\text { originated from the South China } \\
\text { Sea }\end{array}$ & $\begin{array}{l}\text { A total of } 69 \text { marine fish samples } \\
\text { from } 12 \text { different species }\end{array}$ & $\begin{array}{l}\text { Thunnus tonggol }(0.5 \mu \mathrm{g} / \mathrm{g} \mathrm{DW}) \text { and Rastrelliger } \\
\text { brachsoma }(0.45 \mu \mathrm{g} / \mathrm{g} \mathrm{DW}) \text { had the highest level } \\
\text { of mercury compared to other species. }\end{array}$ & Hajeb et al. (2009) \\
\hline $\begin{array}{l}\text { Fishermen boat at fish landings in } \\
\text { Kuantan, Chendering, and Kuala } \\
\text { Perlis }\end{array}$ & $\begin{array}{l}\text { A total of } 69 \text { samples of } \\
\text { short-bodied mackerel and } \\
\text { longtail tuna }\end{array}$ & $\begin{array}{l}\text { Total mercury in all samples ranged from } 0.180 \text { to } \\
1.460 \mu \mathrm{g} / \mathrm{g} \text { DW. Samples of both species from } \\
\text { east coast showed higher levels compared to the } \\
\text { west coast. }\end{array}$ & Hajeb et al. (2010) \\
\hline $\begin{array}{l}\text { Local LKIM fish market from Johor, } \\
\text { Melaka, and Negeri Sembilan }\end{array}$ & $\begin{array}{l}\text { A total of } 162 \text { demersal marine } \\
\text { fish from five species }\end{array}$ & $\begin{array}{l}\text { Range of } \mathrm{Hg} \text { in muscle tissue were between } 0.012 \\
\text { and } 0.019 \mu \mathrm{g} / \mathrm{g} \mathrm{DW}\end{array}$ & $\begin{array}{r}\text { Kamaruzaman } \\
\text { et al. }(2011)\end{array}$ \\
\hline $\begin{array}{l}\text { Ten identified fish landing areas } \\
\text { along the Strait of Malacca }\end{array}$ & $\begin{array}{l}\text { A total of } 60 \text { marine fish from } \\
12 \text { species of most popular } \\
\text { and preferred by local consumers }\end{array}$ & $\begin{array}{l}\mathrm{Hg} \text { levels in demersal fish ranging from } 0.0017 \text { to } \\
0.0065 \mathrm{ppm} \mathrm{WW} \text {. In pelagic fish the range was } \\
\text { between } 0.001 \text { and } 0.0065 \mathrm{ppm} \text {. None of the } \\
\text { samples exceeded the permitted levels. }\end{array}$ & Alina et al. (2012) \\
\hline $\begin{array}{l}\text { Cabang Tiga Kelantan, Kuala } \\
\text { Terengganu, Mersing, Parit } \\
\text { Jawa, Port Dickson, and Langkawi }\end{array}$ & $\begin{array}{l}\text { A total of } 102 \text { samples from } 13 \\
\text { species of marine fish }\end{array}$ & $\begin{array}{l}\text { Mercury levels in fish muscle ranged from less than } \\
0.05 \text { to } 0.67 \mu \mathrm{g} / \mathrm{g} \mathrm{DW} \text {. The highest } \mathrm{Hg} \text { was } \\
\text { determined in Fork-tailed threadfin bream and } \\
\text { bigeye scads. }\end{array}$ & $\begin{array}{l}\text { Agusa et al. } \\
\text { (2007) }\end{array}$ \\
\hline Pulau Tuba, Langkawi & $\begin{array}{l}\text { A total of } 76 \text { marine fish samples } \\
\text { from eight different species }\end{array}$ & $\begin{array}{l}\text { Mercury levels in fish were very much lower } \\
\text { compared to the permissible limits set by the FAO/ } \\
\text { WHO in } 1984 \text {, ranging from } 0.02 \text { to } 0.08 \mathrm{ppm} \mathrm{DW}\end{array}$ & $\begin{array}{l}\text { Irwandi and } \\
\text { Farida (2009) }\end{array}$ \\
\hline
\end{tabular}

study explained this facts where mercury levels in carnivorous fish is more than 1.3 times higher as compared to the levels in herbivorous fish. Another study conducted at Tapajos River basin in the Munduruku Reserve, Jacareacanga, Brazil, showed that the mean mercury concentrations in carnivorous fish $(0.297 \mu \mathrm{g} / \mathrm{g})$ was three times higher when compared to the non-carnivorous species $(0.095 \mu \mathrm{g} / \mathrm{g})$ (Brabo et al. 2000). An earlier study conducted at the same river basin showed the differences of up to seven times between non-carnivorous and carnivorous fish (Bidone et al. 1997). The differences were even more in fish captured from the municipality of Itaituba, Tapajos River Basin, Para, Brazil, where mercury concentrations in carnivorous fish ranged from 112.4 to $2,250 \mu \mathrm{g} / \mathrm{g}$ compared to the detrivorous, herbivorous, and omnivorous that ranged from 3.2 to $309.8 \mu \mathrm{g} / \mathrm{g}$ (dos Santos et al. 2000). Another study by Seixas et al. (2013) showed that the mudeater iliophagous fish were the food items to the voracious predator, and they were also indirectly transmitted the methylmercury to this top predator. Ferriss et al. (2014) had developed models that capable of exploring variations in the concentrations of mercury in top pelagic predators relative to food web structure and mercury input at the base of the system. The data from this study is consistent with those previous studies where the mercury levels in fish with higher tropic level were significantly higher than in fish with lower tropic level. Mercury accumulation through the food chain resulted in higher mercury concentrations in predator fish when compared to fish with lower tropic level.

Although tropic level correlations with mercury in fish have been reported in many studies (Kinghorn et al. 2007; Evans et al. 2005; Burger et al. 2001; Brabo et al. 2000; dos
Santos et al. 2000; Burger and Gochfeld 2011), it was not the only factor that affects mercury contamination in fish (Burger and Gochfeld 2011). Another important factor for mercury contamination in fish was found to be the bioaccumulation process based on its bioavailability, uptake, and toxicokinetics (Burger et al. 2001). Other additional recorded factors were physiological differences between different fish species, migration from unpolluted areas to relatively more polluted areas (Al-Majed and Preston 2000), total organic carbon, biologic activity, $\mathrm{pH}$, conductance, oxygen concentration, water temperature, water level, wetland runoff (Kinghorn et al. 2007), seasons, and habitat (Saei-Dehkordi et al. 2010).

The results for total mercury in demersal fish from this study showed higher levels of mercury, of nearly two times more than in the pelagic fish. Among demersal fish, the highest values corresponded to the smaller species (N. furcosus, Nemipterus thosaporni, N. nematophorus), large demersal species (L. argentimaculatus, Lutjanus russelli), and benthic species (Dasyatis zugei, H. uarnak). The benthic species exhibited high concentrations of mercury than those of pelagic species. This reflected the area variations that may be due to the highest values of mercury in the marine environment where high methylation rates occurred (Arcos et al. 2002; Joiris et al. 1999). Benthic species are more exposed to higher concentrations of methylmercury in the sediment (Al-Majed and Preston 2000) and of their specific prey (Eagle-Smith et al. 2008). Methylation processes are important in the subthermocline waters of the open ocean where low oxygen conditions favor those organisms that transform inorganic mercury into organic forms (Arcos et al. 2002). 
In addition to natural inputs, local pollution in the areas where the fish were captured could explain the concentrations of mercury for this study. Most of the fish samples in this study were of local origin, and they were mainly harvested from the South China Sea and the Strait of Malacca. The countries surrounding the South China Sea are among the most densely populated, fastest growing and until 1997, the most vibrant economies on earth. There would have been introduced wastes from large cities (sewage, industrial waste, and hydrocarbons) and agricultural runoff (nutrients, pesticides and sediment) into the sea (Morton and Blackmore 2001). Besides, the Strait of Malacca contained waste discharged from both land-based and sea-based sources (Chua et al. 2000). For example, this is the area where vessels operate, also hustles of activities from gas platforms activities as well as a consequence of accidents. High concentrations of heavy metal were reported in the waters off the southern coast of Singapore and near petroleum refineries, and it was also detected in bottom sediment, especially in areas experiencing heavy shipping traffic (Chua et al. 2000).

In this study, with mercury contamination being higher in fish samples collected from Port Klang, Selangor, it would reflect urban contamination from the large cities of Kuala Lumpur and Shah Alam, Selangor, and also from shipping activities around Port Klang itself. Mercury contamination in fish collected from Pandan Johor would have been a result of urban activities of Johor Bahru, as well as from the nearby Keppel Harbour and the main port of Singapore (Chua et al. 2000). For Kuala Besar, Kelantan, which is situated at the east coast of Peninsular Malaysia, higher mercury contamination was a result of pollution from anthropogenic activities in the South China Sea coastal waters (Liu et al. 2014), oil well activities in the surrounding area, petroleum refineries, and oil tanker movements (Morton and Blackmore 2001). Resuspension and deposition of dissolved and particulate matter by rain were also major sources of metal pollution in Asian marginal seas (Macdonald et al. 2002; Liu et al. 2014). Understanding the migration patterns and origins of fish are also important factors as the seasonal variation in mercury probably reflects movements of fish of various sources and sizes (Gochfeld et al. 2012). It would seem that a combination of the several factors listed here were responsible for the differences of mercury body burdens between the different species of fish in this study.

A positive relationship between total mercury levels and fish size were often observed indicating that mercury levels tend to increase over time during the growth of the fish (Burger et al. 2001, 2007; Cai et al. 2006; Adams and McMichael 2007; Burger 2009; Burger and Gochfeld 2011; Gochfeld et al. 2012; Seixas et al. 2013; Horvat et al. 2014). In this study, a positive relationship between mercury content and weight was more apparent than when compared to the fish length. These relationships are influenced by the relatively slow rate of mercury eliminated when compared to the rate of its accumulation in fish tissues (Adams and McMichael 2007). Mercury elimination rates for fish tend to decrease with increasing fish body size (Adams and McMichael 2007) as elimination rate is negatively correlated with size (Trudel and Rasmussen 1997). Larger fish usually are older and have had longer time to accumulate mercury (Gochfeld et al. 2012) from their environment. Moreover, they may eat larger prey and varieties of other species of prey that are already highly contaminated with mercury (Adams and McMichael 2007; Gochfeld et al. 2012). Length (Weis 2004; Kinghorn et al. 2007; Li et al. 2009) and weight (Al-Majed and Preston 2000) were used as standard indicators of fish age and were usually used as proxy measurements for age as it was easy to determine in the field (Kinghorn et al. 2007). As a result, in older or longer or bigger fish, mercury concentration was expected to increase unless elimination took place and/or the fish migrated from the polluted area to a relatively less or unpolluted area.

The results of this study will contribute toward the baseline data and information on mercury concentration in marine fish that are commonly consumed in Peninsular Malaysia. This study has identified lower mercury levels in marine fish according to the guidelines; thus, commercial marine fish from Peninsular Malaysia is considered safe for human consumption. It would be appropriate to note that the risk from mercury contaminations could still have an impact on human health if fish were to be consumed in excessive amounts. This is especially so when one refers to the fish species found to have medium to very high levels of mercury contamination; hence, these data would be invaluable as it would provide useful information for assessment of potential health risks from mercury contamination in the populations of Peninsular Malaysia.

\section{Conclusion}

This study evaluated mercury concentrations in 46 species of commonly consumed marine fish sampled from fish landing ports and wholesale markets in Peninsular Malaysia. The data provided information and served as baseline reference for future studies concerning mercury contaminations in marine fish for the country. The edible portion of marine fish contained mercury at low levels and were within the permissible limits by both national and international guidelines. The results from this study also showed that the total mercury concentration in marine fish was positively correlated with length and weight, in that it reflected an accumulation of mercury with time. In addition, the mercury concentrations were found to be higher in carnivorous fish when compared to the herbivorous. Mercury concentrations were also higher in demersal fish, especially the benthic species than their levels in the pelagic species. Mercury concentration in fish collected 
from regions with highly anthropogenic input such as large cities industrial and shipping activities were significantly higher when compared to fish collected from less contaminated regions. Thus, it explained that there was a geographical variability without underestimating the natural sources. There is a need for future studies to measure methylmercury levels in fish to reflect the actual levels of methylmercury contamination in Malaysia.

Acknowledgments The authors acknowledge the support and assistance provided by the staff of the Environmental Health Research Centre, Institute for Medical Research. The authors also acknowledge the Fisheries Development Authority of Malaysia and the Malaysian Fisheries Society, for facilitating the sampling process. We thank the DirectorGeneral of Health, Ministry of Health Malaysia, for permission to publish this article. This study was sponsored by the National Institute of Health (NIH), Ministry of Health Malaysia (project number NON CAM-JPPIMR-07-025).

Open Access This article is distributed under the terms of the Creative Commons Attribution License which permits any use, distribution, and reproduction in any medium, provided the original author(s) and the source are credited.

\section{References}

Adams DH, McMichael RH Jr (2007) Mercury in King Mackerel, Scomberomorus cavalla and Spanish mackerel, S. maculates, from waters of the south-eastern USA: regional and historical trends. Mar Freshwat Res 58:187-193

Agusa T, Kunito T, Yasunaga G, Iwata H, Subramanian A, Ismail A, Tanabe S (2005a) Concentration of trace elements in marine fish and its risk assessment in Malaysia. Mar Pollut Bull 51:896-911

Agusa T, Kunito T, Iwata H, Monirith I, Tana TS, Subramanian A, Tanabe S (2005b) Mercury contamination in human hair and fish from Cambodia: levels, specific accumulation and risk assessment. Environ Pollut 134:79-86

Agusa T, Kunito T, Sudaryanto A, Monirith I, Supawat KA, Iwata H, Ismail A, Sanguamsin J, Muchtar M, Touch ST, Tanabe S (2007) Exposure assessment for trace elements from consumption of marine fish in Southeast Asia. Environ Pollut 145(3):766-777

Alina M, Azrina A, Mohd Yunos AS, Mohd Zakiuddin S, Mohd Izuan Effendi H, Muhammad Rizal R (2012) Heavy metal (mercury, arsenic, cadmium, plumbing) in selected marine fish and shellfish along the Strait of Malacca. Int Food Res J 19(1):135-140

Al-Majed NB, Preston MR (2000) An assessment of the total and methyl mercury content of zooplankton and fish tissue collected from Kuwait Territorial Waters. Mar Pollut Bull 40(4):298-307

Arcos JM, Ruiz X, Bearhop S, Furness RW (2002) Mercury levels in seabirds and their fish prey at the Ebro Delta (NW Mediterranean): the role of trawler discards as sources of contamination. Mar EcolProg Ser 232:281-290

Bidone ED, Castilhos ZC, Cid de Souza TM, Lacerda LD (1997) Fish contamination and human exposure to mercury in the Tapajos River Basin, Para State, Amazon, Brazil: a screening approach. B Environ Contam Tox 59:194-201

Brabo ES, Santos EO, de Jesus IM, Mascarenhas AFS, Faial KF (2000) Mercury contamination of fish and exposure of an indigenous community in Para State, Brazil. Environ Res Sec A 84:197-203
Burger J (2009) Risk to consumers from mercury in bluefish (Pomatomus saltatrix) from New Jersey: size, season and geographical effects. Environ Res 109:803-811

Burger J, Gochfeld M (2011) Mercury and selenium levels in 19 species of saltwater fish from New Jersey as a function of species, size and season. Sci Total Environ 409:1418-1429

Burger J, Gaines KF, Boring CS, Stephens WL, Snodgrass J, Gochfeld M (2001) Mercury and selenium in fish from the Savannah River: species, trophic level and locational differences. Environ Res Sec A 87:108-118

Burger J, Gochfeld M, Jeitner C, Burke S, Stamm T, Snigaroff R, Snigaroff PR, Weston J (2007) Mercury levels and potential risk from subsistence foods from the Aleutians. Sci Total Environ 384:93-105

Cai Y, Rooker JR, Gill G (2006) Bioaccumulation of mercury in pelagic fish in NW Gulf of Mexico and its relationship with length, location, collection year and trophic level. Gulf and Caribbean Fisheries Institute. 57;317-326. http://proc2gcfi.org/pdf/gcfi-24.pdf. Accessed 4 May 2012

Castro-Gonžalez MI, Mendez-Armenta M (2008) Heavy metal: implications association to fish consumption. Environ Toxicol phar 26:263-271

Cheevaporn V, Velasquez I, Menasveta P (2000) Amplication of mercury concentrations in the marine food chain of the East Coast of Thailand. Thammasat Int J Sci Tech 5(2):24-33

Chua TE, Gorre IRL, Ross SA, Bernard SR, Gervacio B, Ebarvia MC (2000) The Malacca Straits. Mar Pollut Bull 41(1-6):160-178

Chvojka R, Williams RJ, Fredrickson S (1990) Methyl mercury, total mercury, and selenium in snapper from two areas of the New South Wales coast, Australia. Mar Pollut Bull 21(12):570-573

Clarkson TW, Magos L (2006) The toxicology of mercury and its chemical compounds. Crit Rev Toxicol 36:609-662

Clarkson TW, Magos L, Myers GJ (2003) The toxicology of mercurycurrent exposures and clinical manifestations. New Engl J Med 349: 1731-1737

Denton GRW, Concepcion LP, Wood HR, Morrison RJ (2006) Trace metals in marine organisms from four harbours in Guam. Mar Pollut Bull 52:1784-1832

dos Santos LS, Muller RC, de Sarkis JSS, Alves CN, Brabo ES, Santos EO, Bentes MH (2000) Evaluation of total mercury concentrations in fish consumed in the municipality of Itaituba, Tapajos River Basin, Para, Brazil. Sci Total Environ 261:1-8

Eagle-Smith CA, Suchanek TH, Colwell AE, Anderson NL (2008) Mercury trophic transfer in a eutrophic lake: the importance of habitat-specific foraging. Ecol Appl 18(8):A196-A212

Evans MS, Lockhart WL, Doetzel L, Low G, Muir D, Kidd K, Stephens G, Dolaronde J (2005) Elevated mercury concentrations in fish in lakes in the Mackenzie River Basin: the role of physical, chemical and biological factors. Sci Total Environ 351-352:479-500

FAO/WHO (2006) Evaluation of certain food additives and contaminants. Sixty-seventh report of the Joint FAO/WHO Ezpert Committee on Food Additives. WHO technical report series. No 940

Ferriss BE, Essington TE (2014) Does trophic structure dictate mercury concentrations in top predators? A comparative analysis of pelagic food webs in the Pacific Ocean. Ecol Model 278:18-28

International Law Book Services (2006) Food act 1983 (Act 281) \& regulations - laws of Malaysia. Petaling Jaya, Selangor

Gochfeld M, Burger J, Jeitner C, Donio M, Pittfield T (2012) Seasonal, locational and size variations in mercury and selenium levels in striped bass (Morone saxatilis) from New Jersey. Environ Res 112:8-9

Guerin T, Chekri R, Vastel C, Sirot V, Volatier JL (2011) Determination of 20 trace elements in fish and other seafood from the French market. Food Chem 127:934-942

Hajeb P, Jinap S (2011) Mercury exposure through fish and seafood consumption in the rural and urban coastal communities of Peninsular Malaysia. World J of Fish and Mar Sci 3(3):217-226 
Hajeb P, Jinap S, Ismail A, Fatimah AB, Jamilah B, Abdul Rahim M (2009) Assessment of mercury level in commonly consumed marine fishes in Malaysia. Food Control 20:79-84

Hajeb P, Jinap S, Ahmad I (2010) Biomagnifications of mercury and methylmercury in tuna and mackerel. Environ Monit Assess 171: 205-217

Horvat M, Degenek N, Lipej L (2014) Trophic transfer and accumulation of mercury in ray species in coastal waters affected by historic mercury mining (Gulf of Trieste, Northern Adriatic Sea). Environ Sci Pollut R 21:4163-4176

Ikem A, Egiebor NO (2005) Assessment of trace elements in canned fishes (mackerel, tuna, salmon, sardines and herrings) marketed in Georgia and Alabama (United States of America). J Food Compos Anal 18:771-787

Ikemoto T, Tu NPC, Okuda N, Iwata A, Omori K, Tanabe S, Tuyen BC, Takeuchi I (2008) Biomagnification of trace elements in the aquatic food web in the Mekong Delta, South Vietnam using stable carbon and nitrogen isotope analysis. Arch Environ Contam Toxicol 54:504-515

Irwandi J, Farida O (2009) Mineral and heavy metal contents of marine fin fish in Langkawi Island, Malaysia. Int Food Res J 16:105-112

Joiris CR, Holsbeek L, Moatemri NL (1999) Total and methylmercury in sardines Sardinella aurita and Sardina pilchardus from Tunisia. Mar Pollut Bull 38(3):188-192

Kamaruzaman BY, Rina Z, John BA, Jalal KCA (2011) Heavy metal accumulation in commercial important fishes of South West Malaysian Coast. Res J Environ Sci 1-8

Khaniki GRJ, Alli I, Nowroozi E, Nabizadeh R (2005) Mercury contamination in fish and public health aspects: a review. Pak J Nutr 4(5): 276-281

Kinghorn A, Solomon P, Chan HM (2007) Temporal and spatial trends or mercury in fish collected in the English Wabigoon river system in Ontario, Canada. Sci Total Environ 372:615-623

Larsen R, Eilertsen KE, Elvevoll EO (2011) Health benefits of marine foods and ingredients. Biotechnol Adv 29:508-518

Li S, Zhou L, Wang H (2009) Feeding habits and habitats preferences affecting mercury bioaccumulation in 37 subtropical fish species from Wujiang River, China. Ecotoxicology 18:204-210

Liu L, Xu X, Yu S, Cheng H, Hong Y, Feng X (2014) Mercury pollution in fish from South China Sea: levels, species-specific accumulation and possible sources. Environ Res 131:160-164

Macdonald RW, Morton B, Addison RF, Johannessen SC (2002) Marine environmental contaminant issues in the North Pacific: What are the dangers and how do we identify them? In: Perry RI, Livingston P, Bychkov AS (eds) Pices science: the first ten years and a look to the future. Pices Scientific Report No. 22. http://pices.int/publications/ scientific reports/Report22/Macdonald.pdf.

McManus A, Feilder L, Newton W, White J (2011) Health benefits of seafood for men. J Men's Health 8(4):252-257

Mendil D, Demirci Z, Tuzen M, Soylak M (2010) Seasonal investigation of trace element contents in commercially valuable fish species from the black sea, Turkey. Food Chem Toxicol 48:865-870

Mohd Fairulnizal MN, Tumijah AH, Zakiah I (1998) Determination of mercury in urine by on-line digestion with a flow injection mercury system. Atom Spectrosc 19(3):95-99

Mok WJ, Senoo S, Itoh T, Tsukamasa Y, Kawasaki K, Ando M (2012) Assessment of concentrations toxic elements in aquaculture food products in Malaysia. Food Chem 133:1326-1332

Morgano MA, Rabonato LC, Milani RF, Miyagusku L, Balian SC (2011) Assessment of trace elements in fishes of Japanese foods marketed in Sao Paulo (Brazil). Food Control 22:778-785

Morton B, Blackmore G (2001) South China Sea. Mar Pollut Bull 42(12): $1236-1263$

Murphy TP, Irvine KN, Sampson M, Guo J, Parr T (2008) Mercury contamination along the Mekong River, Cambodia. Asian J Water Environ Pollut 6(1):1-9
Myers GJ, Davidson PW (2000) Does methylmercury have a role in causing development disabilities in children? Environ Health Persp 108(3):413-420

Myers GJ, Davidson PW, Cox C, Shamlaye C, Cernichiari E, Clarkson TW (2000) Twenty-seven years studying the human neurotoxicity of methylmercury exposure. Environ Res 83A:275-285

Norimah AK, Safiah M, Jamal K, Haslinda S, Zuhaida H, Rohida S, Fatimah S, Azlin S, Poh BK, Kandiah M, Zalilah MS, Wan Manan WM, Fatimah S, Azmi MY (2008) Food consumption patterns: findings from the Malaysian adult nutrition survey (MANS). Mal J Nutr 14(1):25-39

Nurnadia AA, Azrina A, Amin I (2011) Proximate composition and energetic value of selected marine fish and shellfish from the West Coast of Peninsular Malaysia. Int Food Res J 18: $137-148$

Saei-Dehkordi SS, Fallah AA, Nematollahi A (2010) Arsenic and mercury in commercially valuable fish species from the Persian Gulf: influence of season and habitat. Food Chem Toxicol 48:2945-2950

Seixas TG, Moreira I, Malm O, Kehrig HA (2013) Ecological and biological determinants of methylmercury accumulation in tropical coastal fish. Environ Sci Pollut R 20:1142-1150

Soegianto A, Moehammadi N, Irawan B, Affandi M, Hamami (2010) Mercury concentrations in edible species harvested from Gresik Coast, Indonesia and its health risk assessment. Cah Biol Mar $51: 1-8$

Sompongchaiyakul P, Hantow J, Sornkrut S, Sumontha M, Jayasinghe RPPK (2011) An assessment of mercury concentration in fish tissues caught from three compartments of the Bay of Bengal. In: Harper S, O'Meara D, Booth S, Zeller D, Pauly D (eds) Fisheries catches for the Bay of Bengal large marine ecosystem since 1950, vol 16, Report to the Bay of Bengal large marine ecosystem project. BOBLME-2011-Ecology-., pp 221-232

Stergiou KI, Karpouzi VS (2002) Feeding habits and trophic levels of Mediterranean fish. Rev Fish Biol Fish 11:217-254

Stergiou KI, Karpouzi VK (2005) The trophic position of fishes in Hellenic Marine Ecosystems. In: Papathanassiou E, Zenetos A (eds). State of the Hellenic marine environment, Hellenic Center for the Marine Research, Athens, Greece, p 280-284

Streets DG, Hao J, Wu Y, Jiang J, Chan M, Tian H, Feng X (2005) Anthropogenic mercury emissions in China. Atmos Environ 39: 7789-7806

Tee ES, Mohd Ismail N, Mohd Nasir A, Khatijah I (1997) Nutrient composition of Malaysian foods, ASEAN sub-committee on protein: food habits research and development. Institute for Medical Research, Kuala Lumpur

Tey YS, Shamsudin MN, Mohamed Z, Abdullah AM, Radam A (2008) Complete demand systems of food in Malaysia. Agr Econ - Czech 10:467-475

Tollefson L, Cordle F (1986) Methylmercury in fish: a review of residue levels, fish consumption and regulatory action in the United States. Environ Health Persp 68:203-208

Torpy JM (2006) Eating fish: health benefits and risks. J Amer Med Assoc 296(15):1926

Trudel M, Rasmussen JB (1997) Modelling the elimination of mercury by fish. Environ Sci Technol 31:1716-1722

Turkmen A, Turkmen M, Tepe Y, Akyurt I (2005) Heavy metals in three commercially valuable fish species from Iskenderun Bay, Northern East Mediterranean Sea Turkey. Food Chem 91:167-172

Weis IM (2004) Mercury concentrations in fish from Canadian Great Lakes areas of concern: an analysis of data from the Canadian department of environment database. Environ Res 95:341-350

Yilmaz AB, Sangun MK, Yaglioglu D, Turan C (2010) Metals (major, essential to non-essential) composition of the different tissues of three demersal fish species from Iskenderun Bay, Turkey. Food Chem 123:410-415 